\title{
Meeting materials from the 3rd Annual Meeting of the International Society for the Prevention of Tobacco Induced Diseases
}

Published: 15 December 2004

Tobacco Induced Diseases 2004, 2:168 doi:10.1 186/1617-9625-2-4-168

This article is available from: http://www.tobaccoinduceddiseases.com/content/2/4/168

(c) 2004 licensee BioMed Central Ltd.

This is an Open Access article distributed under the terms of the Creative Commons Attribution License (http://creativecommons.org/licenses/by/2.0), which permits unrestricted use, distribution, and reproduction in any medium, provided the original work is properly cited.

The meeting materials from the 3rd Annual Meeting of the International Society for the Prevention of Tobacco Induced Diseases are available as a zip drive in additional file 1

\section{Additional material}

\section{Additional file 1}

The meeting materials from the 3rd Annual Meeting of the International Society for the Prevention of Tobacco Induced Diseases.

Click here for file

[http://www.biomedcentral.com/content/supplementary/1617-

9625-2-4-168-S1.zip] 